\title{
Histone H3.2
}

National Cancer Institute

\section{Source}

National Cancer Institute. Histone H3.2. NCI Thesaurus. Code C148067.

Histone H3.2 (136 aa, 15 kDa) is encoded by the human H3C13, H3C14 and H3C15

genes. This protein plays a role in nucleosome remodeling and chromosomal structure. 